Vol. 16 (2007): 147-156

\title{
Inbreeding and relationship coefficients in the Finnish blue fox population
}

\author{
Ismo Strandén and Jussi Peura \\ MTT Agrifood Research Finland, Biotechnology and Food Research, Biometrical Genetics, \\ FI-31600 Jokioinen, Finland, e-mail: ismo.stranden@mtt.fi
}

\begin{abstract}
Animal size has increased considerably in the Finnish blue fox population. This has been achieved by intensive selection. An efficient breeding scheme may increase inbreeding. The rate of inbreeding by generation was estimated to be from $0.107 \%$ to $0.191 \%$ depending on the considered years. Annual rate of inbreeding was estimated to be from $0.059 \%$ to $0.100 \%$ depending on the considered years. Effective population size was estimated to be at least 260 . Thus, inbreeding seems not a major problem in the Finnish blue fox population. However, some of the best breeding farms in terms of estimated genetic level in animal size have the highest average inbreeding coefficient, as well. Advanced tools to restrict increase in coefficient of inbreeding may be needed in the future, and in some farms already.
\end{abstract}

Key-words: breeding scheme, fur animals, inbreeding

\section{Introduction}

Animal breeding may unintentionally reduce the value of economically important traits or the welfare of animals. The aim of selective breeding is to increase or decrease selected target traits such as the animal skin or litter size. The selected animals tend to be genetically alike and, after several generations of selection, are often close relatives. Thus, it is well known that an efficient breeding scheme tends to increase inbreeding. When production traits are overly emphasized in selection, inbreeding in presence of dominance gene action leads to inbreeding depression. The animal size of the Finnish blue fox has greatly increased during the last 10-15 years but litter size has decreased in recent years (Peura et al. 2004). The decrease in 
Strandén, I. \& Peura, J. Inbreeding and relationship coefficients in the Finnish blue fox population

litter size could be mostly due to an unfavorable correlation between these two traits (Peura et al. 2004, Peura et al. 2007). However, the decrease in recent years could be partly due to inbreeding, because artificial insemination has become more popular, allowing the use of only a limited number of males in breeding.

The level and effect of inbreeding have seldom been studied in fur animal populations. Wierzbicki et al. (2004) found the highest average inbreeding coefficient for a group of animals born in the last study year to be about $1 \%$ in the Finnish blue fox population. However, they did not estimate rate of inbreeding, and their data contained only a couple of farms. Effect of inbreeding on litter size is more studied. Nordrum (1994) found a decrease in litter size of 0.41 pups per $10 \%$ increase in inbreeding coefficient among blue foxes in Norway. Wierzbicki et al. (2004) studied the effect of inbreeding in Polish and Finnish fur populations. They considered several traits, and found the most noticeable effect on litter size in the Finnish blue fox population: $10 \%$ increase in inbreeding coefficient decreased litter size by 0.47 pups. Thus, effect of inbreeding on blue fox production can be large because litter size has the highest economic weight with economic value of about $23 €$ per pup (Peura et al. 2005). Because average litter size is about six pups (Peura et al. 2005, Wierzbicki et al., 2004), loss of 0.47 pups means almost $8 \%$ decrease in number of pups. Loss of income is even more than $8 \%$ because added cost of keeping more pups is marginal. Thus, every percentage increase in inbreeding coefficient translates into equally high decrease in income.

Selection decisions in fur breeding are affected by annual changes in market prices. For example, lower than expected skin prices rapidly lead to a decrease in production. Rapid control of the population size is possible because the generation interval is less than 2 years (Kenttämies et al. 2002). Genetic links between farms are quite loose. There are some fox breeding circles that exchange breeding material using artificial insemination. Most breeding schemes rely on quite large population sizes and short generation intervals. Because foxes have no efficient national breeding scheme, such as in dairy cattle and pigs, it is likely that the best breeding practices are concentrated on a relatively small number of farms.

It can be hypothesized that animal breeding is efficient in some top farms. Higher than average inbreeding coefficient on a farm may be a sign of an efficient breeding scheme. On the other hand, inbreeding can become a problem on some farms but cannot be observed at the population level statistics. Thus, inbreeding and the efficiency of breeding schemes need to be considered together.

The purpose of this study was to examine trends in the average inbreeding coefficient and the coefficient of relationship in the Finnish blue fox population. The effective population size was estimated. In addition, farms with high average inbreeding coefficient were compared to the whole population in terms of within-farm genetic level in animal size.

\section{Material and methods}

\section{Pedigree}

Data were obtained from the Sampo register for which the records are collected from farms and maintained by the Finnish Fur Breeders' Association. The data are most complete from 1990 onwards, but there are records of some animals from the 1970s. Some farms have no genetic ties to other farms, or the relationships are unknown because these farms have joined the register recently or for some other reason. Consequently, averages for relationship statistics were calculated from farms having genetic ties.

Averages were calculated from a selected set of farms. The sampled farms were required to have at least 50 breeding foxes annually in 5 consecutive years within the period from 1990 to 2004 . The presented statistics will be means of farm averages by year. In order to avoid giving too much weight to small farm years, number of animals on a farm had to be 10 or more in a birth year in order to be included in the statistics. 
Vol. 16 (2007): 147-156

The complete pedigree had about 4.1 million animals, of which about 3.3 million were blue foxes. The pedigree had 215 farms that fulfilled the above selection criteria but number of farms varied by year because not all farms had enough breeding animals to be included in the statistics (Table 1). The sampled farms had about 3.2 million blue foxes. Most of the animals are pelted the year they are born. Only fraction of animals will be used for production and breeding purposes. Number of breeding animals was 237487 during 1990 to 2003 (Table 2). These animals are of most interest in our study. All statistics are from the animals in the selected 215 farms, although the inbreeding and relationship coefficient calculations used information from the complete pedigree.

\section{Measures of relationship}

Two measures of relationship were calculated: coefficients of relationship and inbreeding (Wright 1922). The coefficient of inbreeding for animal $i$ is
Table 1. Number of farms $\left(\mathrm{N}_{\text {Farm }}\right)$, median $(\mathrm{M})$, average $(\mathrm{N})$, minimum (Min) and maximum (Max) number of breeding animals on farms by birth year.

\begin{tabular}{cccccc}
\hline Year & $\mathrm{N}_{\text {Farm }}$ & $\mathrm{M}$ & $\mathrm{N}$ & Min & Max \\
\hline 1990 & 75 & 42 & 30 & 10 & 333 \\
1991 & 99 & 59 & 44 & 10 & 324 \\
1992 & 119 & 65 & 49 & 10 & 395 \\
1993 & 141 & 81 & 61 & 10 & 357 \\
1994 & 162 & 87 & 63 & 10 & 387 \\
1995 & 178 & 103 & 75 & 11 & 538 \\
1996 & 199 & 107 & 80 & 10 & 621 \\
1997 & 206 & 108 & 83 & 10 & 607 \\
1998 & 201 & 76 & 57 & 10 & 442 \\
1999 & 207 & 125 & 98 & 11 & 986 \\
2000 & 206 & 128 & 102 & 11 & 917 \\
2001 & 202 & 128 & 94 & 13 & 953 \\
2002 & 175 & 126 & 97 & 12 & 837 \\
2003 & 166 & 107 & 87 & 14 & 710 \\
\hline
\end{tabular}

$F_{i}=\frac{1}{2} a_{s d} \quad$ where $a_{s d}$ equals the numerator of the coefficient of relationship, or in short the relationship coefficient, between the sire and dam of animal $i$. The average coefficient of inbreeding in a population indicates the current inbreeding level. If the aver-

Table 2. Average inbreeding (F), and coefficient of relationship (R) in percentage by birth year. The coefficient of relationship was calculated between all animals $(\mathrm{R})$ and between males and females $\left(\mathrm{R}^{*}\right)$.

\begin{tabular}{|c|c|c|c|c|c|c|c|c|}
\hline \multirow[b]{2}{*}{ Year } & \multicolumn{2}{|c|}{ All animals } & \multicolumn{6}{|c|}{ Breeding animals } \\
\hline & $\begin{array}{c}\text { No. of } \\
\text { animals }\end{array}$ & $\begin{array}{l}\mathrm{F} \\
(\%)\end{array}$ & $\begin{array}{l}\text { No. of } \\
\text { animals }\end{array}$ & $\begin{array}{l}F \\
(\%)\end{array}$ & $\begin{array}{l}\mathrm{R} \\
(\%)\end{array}$ & $\begin{array}{c}\text { No. of } \\
\text { males }\end{array}$ & $\begin{array}{r}\text { No. of } \\
\text { females }\end{array}$ & $\begin{array}{l}\mathrm{R}^{*} \\
(\%)\end{array}$ \\
\hline 1990 & 7985 & 0.10 & 3160 & 0.07 & 3.59 & 338 & 2328 & 2.30 \\
\hline 1991 & 17262 & 0.24 & 5865 & 0.18 & 4.18 & 640 & 4686 & 2.43 \\
\hline 1992 & 42235 & 0.35 & 7749 & 0.30 & 4.58 & 850 & 6494 & 3.66 \\
\hline 1993 & 62024 & 0.50 & 11426 & 0.42 & 4.76 & 1350 & 9387 & 3.53 \\
\hline 1994 & 111607 & 0.57 & 14039 & 0.44 & 4.65 & 1707 & 11797 & 3.38 \\
\hline 1995 & 160675 & 0.64 & 18247 & 0.48 & 4.20 & 2214 & 15488 & 3.26 \\
\hline 1996 & 242717 & 0.65 & 21207 & 0.50 & 4.26 & 2646 & 17303 & 3.18 \\
\hline 1997 & 254437 & 0.67 & 22308 & 0.50 & 4.16 & 2822 & 19048 & 2.88 \\
\hline 1998 & 290798 & 0.66 & 15265 & 0.48 & 4.59 & 2245 & 12570 & 3.50 \\
\hline 1999 & 252185 & 0.68 & 25972 & 0.56 & 5.15 & 2730 & 22757 & 3.73 \\
\hline 2000 & 315153 & 0.76 & 26446 & 0.63 & 5.36 & 3201 & 23102 & 3.76 \\
\hline 2001 & 388059 & 0.89 & 25886 & 0.79 & 5.83 & 3368 & 22505 & 4.21 \\
\hline 2002 & 329298 & 1.01 & 22085 & 0.84 & 5.95 & 2702 & 19355 & 4.46 \\
\hline 2003 & 304257 & 1.09 & 17832 & 0.98 & 6.15 & 2553 & 15119 & 4.57 \\
\hline
\end{tabular}


Strandén, I. \& Peura, J. Inbreeding and relationship coefficients in the Finnish blue fox population

age inbreeding coefficient is high in a population, it may be too late to act. The average relationship coefficient between individuals that are available for breeding predicts the future level in inbreeding coefficient.

The coefficient of relationship $\mathrm{R}$ can be calculated between two groups or between all animals in a group. We considered two cases: the average relationship coefficient between groups of males and females by birth year, and between animals by birth year. Thus, in the first approach relationship coefficients were calculated only between males and females born the same year. But, in the second approach they were calculated also among males and among females.

Comparisons of relationship and inbreeding coefficients are reasonable only for breeding animals. Relationship coefficients for animals without progeny can be contrasted with relationship coefficients for breeding animals but not with inbreeding coefficients, because animals without progeny do not have progeny for which inbreeding has been calculated. Consequently, relationship coefficients are presented for the breeding animals only.

Averages of the coefficients of inbreeding and relationship were calculated by averaging farm averages by birth year of animals. Most of the relationships are between animals in the same farm, i.e., there are few relationship links between farms. Thus, a population average might give too optimistic and large-farm dominated view on the population. The average coefficients calculated over a population would be lower than those calculated using farm averages.

\section{Effective population size}

The effective population size is $N_{e}=1 /(2 \Delta F)$ where $\Delta F$ is rate of inbreeding per generation. The rate of inbreeding is defined as

$$
\Delta F=\frac{F_{t}-F_{t-1}}{1-F_{t-1}}
$$

where $F_{t}$ is the average inbreeding coefficient in generation $t$.

Estimating the rate of inbreeding directly using population values is unreliable when there are overlapping generations. Let $l$ be average generation interval, and $b$ mean increase in inbreeding coefficient by birth year. The average generation interval was estimated as (Rendel \& Robertson 1950) $l=\left(l_{M M}+l_{M F}+l_{F M}+l_{F F}+\right) / 4$ where $l_{M M}, l_{M F}, l_{F M}, l_{F F}$ are lengths of paths males to breed males, males to breed females, females to breed males, and females to breed females, respectively. Because $F_{t}-F_{t-1}=l \times b$, the rate of inbreeding can be expressed as (Gutiérrez et al. 2003)

$$
\Delta F=\frac{l \times b}{1-F_{\text {last }}+l \times b}
$$

where $F_{\text {last }}$ is inbreeding coefficient in the last year studied, Mean increase in inbreeding coefficient was estimated by the regression coefficient of average inbreeding $(b)$ over birth year.

\section{Breeding scheme and inbreeding}

In order to test the hypothesis that high average inbreeding coefficient may be due to an efficient breeding scheme, breeding values in animal size were estimated. Animal size was a subjective grading measurement made by the farmer. In Finland, the grading scale for animal size goes from one to five where one is given to the smallest and five to the largest animals. The grading is done so that the average size is approximately three in a farm each year. The statistical model and variance components were the same as used for the within-farm breeding value estimations used in Finland. However, here the genetic evaluation used the pedigree described above for the inbreeding study, i.e., this was a national evaluation.

The model was

$$
\mathbf{y}=\mathbf{X b}+\mathbf{W c}+\mathbf{Z a}+\mathbf{e}
$$

where $\mathbf{X}, \mathbf{W}$, and $\mathbf{Z}$ are design matrices that relate fixed effects $\mathbf{b}$, the random litter effect of an animal 
Vol. 16 (2007): 147-156

c, and the additive genetic effect $\mathbf{a}$ to the appropriate animal size observation in $\mathbf{y}$, respectively. Above, vector $\mathbf{e}$ has the random residual effects. The fixed effects were the herd-mating year, sex, birth date class since beginning of the year, and age of dam. The random effects were assumed normally distributed with

$$
\mathrm{E}\left(\begin{array}{l}
\mathbf{c} \\
\mathbf{a} \\
\mathbf{e}
\end{array}\right)=\mathbf{0} \text { and } \operatorname{Var}\left(\begin{array}{l}
\mathbf{c} \\
\mathbf{a} \\
\mathbf{e}
\end{array}\right)=\left[\begin{array}{ccc}
\sigma_{c}^{2} \mathbf{I} & \mathbf{0} & \mathbf{0} \\
\mathbf{0} & \sigma_{a}^{2} \mathbf{A} & \mathbf{0} \\
\mathbf{0} & \mathbf{0} & \sigma_{e}^{2} \mathbf{I}
\end{array}\right]
$$

where the variances were $\sigma_{c}^{2}=0.046, \sigma_{a}^{2}=0.111$, and $\sigma_{e}^{2}=0.301$. There were observations from 424578 animals. The pedigree was pruned for the animal size evaluations, because animal size is mostly available for production and breeding animals only. The pruned pedigree had 465534 animals.

The procedure for calculating average genetic level was essentially the same as described above for inbreeding coefficient. Thus, means of withinfarm estimated breeding values were calculated by birth year. These mean within-farm values were then averaged by birth year. The best $10 \%$ of farms in genetic level were considered to be those that had the highest average in estimated breeding value for animal size of breeding animals in year 2002 . Average inbreeding coefficients on these farms were then contrasted with those in the whole population.

\section{Results and discussion}

\section{Numbers of animals and generation interval}

Number of breeding animals born in 1998 was less than in 1997 (Tables 1 and 2). In season 1997-1998, prices of skins dropped considerably, and many farms scaled down their fur production. The number of animals used for breeding thus decreased. In the national population, the number of blue foxes used for breeding in 1999 was about 33\% less than in 1998 because of lower skin prices. The number of breeding males has not regained its former levels. However, in the sample data the numbers of breeding males after 1998 have even exceeded those in the 1997 year class.

The generation interval was estimated for animals born during the years 1994 to 2003 for four paths. The generation interval was 1.59 years for the path from males to breeding males, 1.64 years for the path from males to breeding females, 2.12 years for the path from females to breeding males, and 2.34 years for the path from females to breeding females. Consequently, the mean generation interval was 1.92 years. These generation intervals were somewhat longer than the estimates presented by Kenttämies et al. (2002), according to whom the generation interval for males ranged from 1.3 to 1.7 years, while for females it was 1.8 years. One reason for the shorter intervals in their study is likely to be that they considered only one farm during a 3-year selection experiment.

\section{Inbreeding and relationships}

Increase in average inbreeding coefficient was moderate or even low in the groups of all and breeding animals (Table 2). The averages of inbreeding coefficients for the group of all animals are close to those in Wierzbicki et al. (2004). The mean inbreeding coefficient was lower in the group of breeding animals (Fig. 1). This is likely to be due to deliberate inbreeding to produce the wanted pelt or color type in production animals, or the avoidance of mating close relatives to produce breeding animals. However, there were some individuals used for breeding that had an inbreeding coefficient as high as $37 \%$.

The average increase in inbreeding coefficients estimated through linear regression was $0.056 \%$ per year for the breeding animals during 1990 to 2003. The average inbreeding coefficient of breeding animals has increased at a slightly higher rate since 1997 (Fig. 1). The number of years is quite small, and, because the average inbreeding coef- 


\section{AGRICULTURAL AND FOOD SCIENCE}

Strandén, I. \& Peura, J. Inbreeding and relationship coefficients in the Finnish blue fox population

Fig. 1. Average inbreeding coefficient percentage by birth year in breeding animals (thick solid line), and all animals (thick dotted line). The thin lines are regression lines on the inbreeding lines.

Figure 2. Average relationship coefficient percentage by birth year in breeding animals calculated between males and females (thick solid line), and between all breeding animals (dotted line).
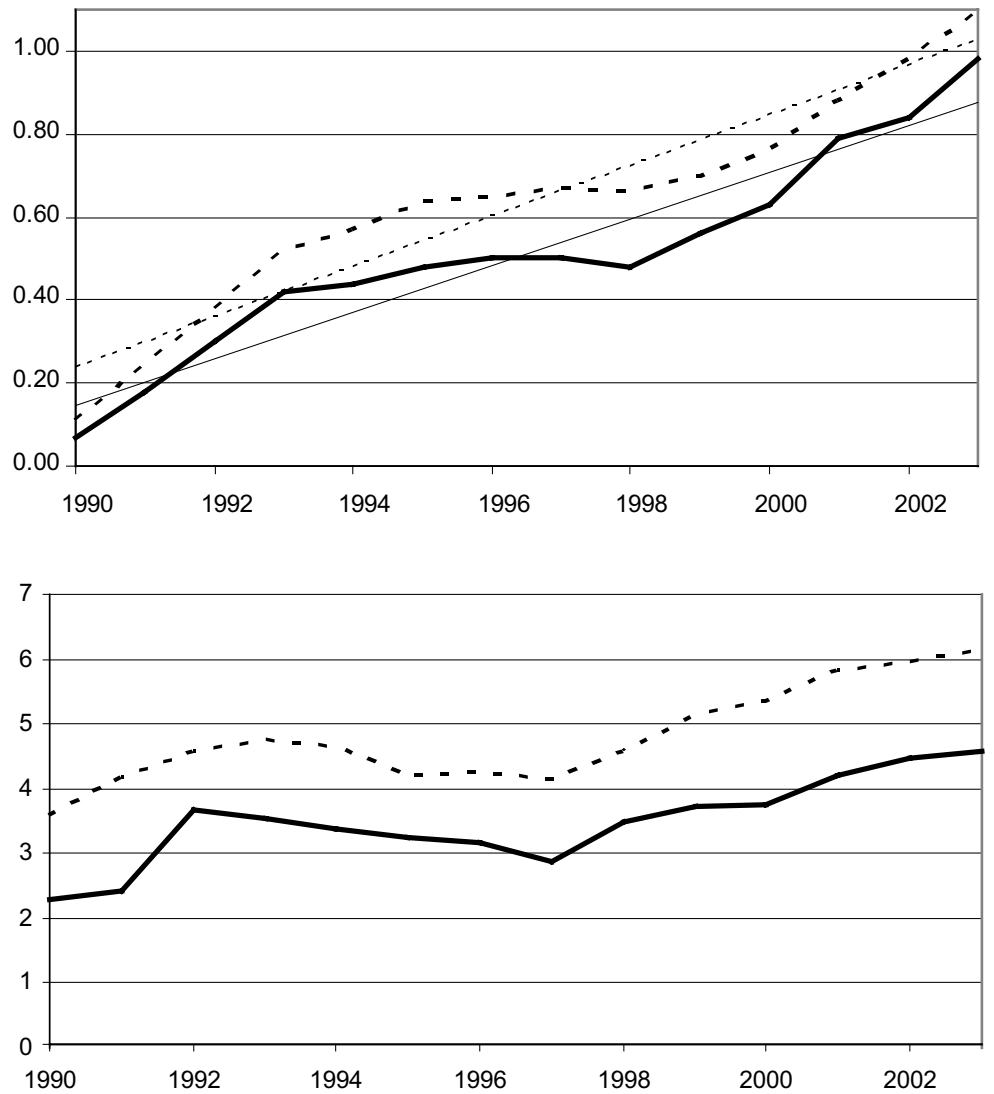

ficient in 1998 was lower than in 1997, the estimation of a new annual increase in inbreeding is unreliable. However, mean inbreeding coefficient increased by about $0.100 \%$ annually during 1998 to 2003, or almost twice of that estimated for the whole study period.

The average relationship coefficient between animals born the same year remained unchanged during 1990 to 1997 (Table 2). In 1998 and 1999 the coefficient increased considerably, after which it has continued to increase moderately (Fig. 2). This sudden increase is due to the decrease in the number of breeding animals in 1998 as already described. Although the numbers of breeding animals have risen in recent years, a bottleneck was created. In addition, as males are used in breeding for about two years, the total number of males used for breeding recovered not as quickly as the numbers of breeding animals shown in the table. Consequently, it is logical that the relationship coefficient has increased over several successive years.

Inbreeding coefficient of an animal is half of the relationship coefficient between its sire and dam. In other words, average relationship coefficient of parents is twice the inbreeding coefficient of their progeny. The average relationship coefficient was larger than twice the average inbreeding coefficient in every birth year class studied when a two year generation interval is considered (Table 2). Thus, the realized inbreeding coefficient was less than that anticipated by the average relationship coefficient. This is most likely due to the applied mating strategy where mating of close relatives is avoided. Another possible, but probably insignificant, reason would be inbreed- 
Vol. 16 (2007): 147-156

ing depression that diminishes number of progeny from a mating of close relatives where relationship coefficient is already high.

In Finland, use of artificial insemination in blue fox breeding gained popularity during the 1990s. At the moment, about $90 \%$ of all matings are through artificial insemination. This technique may tempt some farmers to use too few males in breeding, and it is therefore possible that some of the increase in inbreeding coefficient in recent years can be explained by the increased use of artificial insemination.

\section{Effective population size}

The rate of inbreeding by generation and the effective population size were estimated to be $0.109 \%$ and 459 , respectively, using the figures of $0.056 \%$ by year as increase in inbreeding coefficient, 1.92 year as generation interval, and $0.98 \%$ as average inbreeding coefficient of breeding animals in the last year studied. Thus, annual rate of inbreeding was $0.057 \%$.

In recent years, the average inbreeding coefficient has risen more rapidly than before as already described (Fig. 1). However, no significant change in the average generation interval was observed. Increase in inbreeding coefficient from year 1998 to 2003 was $0.100 \%$ per year. With this estimate the rate of inbreeding by generation, annual rate of inbreeding, and the effective population size would be $0.194 \%, 0.101 \%$ and 258 , respectively. Although the new effective population size estimate is considerably less than for the whole period, it is still reasonably large when compared to estimates for some other breeding populations. For example, Spanish beef breeds have effective populations of 21 to 123 (Gutiérrez et al. 2003) and Finnish Ayrshires from 34 to 40 (Woolliams \& Mäntysaari 1995).

The two estimated annual rates of inbreeding $0.057 \%$ and $0.101 \%$ differ considerably, although both figures are quite low. Thus, fluctuating market prices seem to have a large influence on the number of breeding animals and estimate of rate of inbreeding. In practice, selection of breeding animals needs to be done carefully, in order to avoid an increase in rate of inbreeding.

\section{Pedigree quality and connectedness}

Statistics from the complete pedigree suggest that the pedigree was of good quality. Number of animals for which both parents were known was high during the studied period. It was $84.2 \%$ in $1990,91.9 \%$ in 1991, about $97 \%$ in 1992 and 1993, more than $98 \%$ from 1994 onwards. For the breeding animals, the numbers are lower. Both parents were known for $67 \%$ in 1990 , for $76 \%$ in 1991 , and steadily increasing from $83 \%$ in 1992 to $95 \%$ in 2003 .

Another measure for pedigree quality is pedigree completeness (MacCluer et al. 1983). We calculated pedigree completeness for the breeding animals taking into account five generations. Average pedigree completeness was $58 \%$ for animals born in 2003. A further analysis revealed that pedigree completeness was slightly better for females than for males. Because artificial insemination allows use of males across farms, it can be suspected that parentage information of males is missing when a male from another farm is used. However, in practice, artificial insemination is not widely done across farms although some farms have formed breeding circles. In addition, pedigree completeness increased from one birth year class to the other when use of artificial insemination increased in the 1990s as well. Thus, the reason for lower pedigree quality for males can only be speculated. Reasons can be poor recording practices for males bought from another farm, or incomplete knowledge on the mate because several males have been used to mate the same female during the same mating season.

A method by VanRaden (1992) can be used to calculate inbreeding coefficients when there are problems due to missing parentage information. In this method, inbreeding coefficients of animals with an unknown parent are replaced by mean inbreeding of animals born the same year. Because inbreeding of progeny is changed, the method can be applied iteratively until no change in inbreed- 
Strandén, I. \& Peura, J. Inbreeding and relationship coefficients in the Finnish blue fox population

ing coefficients can be observed. This method increased the average inbreeding coefficients of breeding animals more in the beginning of the period than in the end of the period. Thus, rate of inbreeding would become lower using these values than those estimated earlier from the pedigree.

\section{Inbreeding coefficient and the breeding scheme}

There were 177 farms that had breeding animals born in 2002 in our sample data. Average inbreeding coefficients by farm had a very skewed distribution with considerable proportion of low values. It appears that inbreeding is not a great problem in general, as about $68 \%$ of the farms had lower than $1 \%$ average inbreeding coefficient, while on 5 farms average inbreeding coefficient was above $3 \%$. The farms with the highest mean inbreeding coefficient, denoted by letters from A to E, had average inbreeding coefficient of 3.05, 3.76, 4.12, 4.42 , and 5.29 percent, respectively. The proportion of animals with inbreeding coefficient higher than $5 \%$ was $16,28,42,45$, and 31 percent on farms $A$ to $\mathrm{E}$, respectively.

The top $10 \%$ of farms according to mean estimated breeding value by animal size had average inbreeding coefficient of $1.53 \%$ on year 2002 . Average inbreeding coefficient for the evaluation data set in 2002 was $0.84 \%$. Thus, the higher than average inbreeding coefficient may be an indication of an efficient breeding scheme. Three of the top $10 \%$ farms by estimated breeding value were among those farms mentioned above having coefficient of inbreeding more than $3 \%$.

We observed no significant relationship between average inbreeding coefficient and farm size. However, correlation of farm size and average inbreeding by year was always positive and ranged from $3 \%$ to $17 \%$. Thus, the larger the farm was, the higher average inbreeding coefficient was. This can again be due to more efficient breeding scheme in large farms. The larger farms are likely to be more professional and have an efficient breeding scheme, which leads to higher than average inbreeding coefficients. The large variation in correlation coefficient is likely due to outlier effect. Number of big farms was small. So, one or two farms with large average inbreeding coefficient could affect the statistic.

Inbreeding did not appear to be a common problem, and could become a problem only on certain farms. These farms should buy new breeding material from outside to reduce inbreeding but still have animals of high genetic merit. This may be difficult for some farms, because these are among the top farms. These farms would benefit from using mating planning such as those derived with optimal contribution theory (e.g. Meuwissen 1997, Grundy et al. 1998) that restricts rate of inbreeding but still gives high genetic progress.

In our sample population, the number of males used for breeding during 1994 to 2003 was from 1700 to 3400 per year, while for females the corresponding numbers were 12000 to 23000 per year. It seems that these animal numbers are adequate in restraining inbreeding sufficiently. Artificial insemination and intensified selection can be used to reduce the number of males in breeding. However, this increases the risks for higher inbreeding in a breeding scheme. In the Finnish fur breeding scheme, no full- or half-sib matings are allowed, which inhibits an uncontrolled increase in the mean relationship coefficient and, thus, slows down the increase in the mean inbreeding coefficient. However, some farms might benefit from even more advanced mating plan strategies such as those deduced from optimal contribution theory mentioned above.

\section{Conclusions}

Inbreeding does not appear to be a common problem in the Finnish blue fox population and the effective population size is at an acceptable level. It seems that current practices of avoiding inbreeding work well. In addition, because the average rate of inbreeding is moderate or even low, any deterioration in fertility, health or conformation in the Finnish fur 
Vol. 16 (2007): 147-156

animal population cannot be considered to be due to inbreeding at present. However, some farms may already or in the near future have problems due to inbreeding that may be seen in the smaller than average litter sizes. In these farms, importation of animals from other farms is often the easiest method to halt increase in coefficient of inbreeding.

\section{References}

Grundy, B., Villaneuva, B. \& Woolliams, J.A. 2000. Dynamic selection for maximizing response with constrained inbreeding in schemes with overlapping generations. Animal Science 70: 373-382.

Gutiérrez, J.P., Altarriba, J., Díaz, C., Quintanilla, R., Cañón, J. \& Piedrafita, J. 2003. Pedigree analysis of eight Spanish beef cattle breeds. Genetics Selection Evolution 35: 43-63.

Kenttämies, H., Nordrum, N. Valberg, Brenøe, U.T., Smeds, K., Johannessen, K.R. \& Bakken, M. 2002. Selection for more confident foxes in Finland and Norway: Heritability and selection response for confident behaviour in blue foxes (Alopex lagopus). Applied Animal Behaviour Science 78: 67-82.

MacCluer, J.W., Boyce, A.J., Dyke, B., Weitkamp, L.R., Pfenning, D.W. \& Parsons, C.J. Inbreeding and pedigree structure in Standardbred horses. Journal of Heredity 74:394-399.

Meuwissen, T.H.E. 1997. Maximizing the response of selection with a predefined rate of inbreeding. Journal of Animal Science 75: 934-940.
Nordrum, N.M.V. 1994. Effect of inbreeding on reproductive performance in blue fox (Alopex lagopus) Vixens. Acta Agriculturae Scandinavica, Section A, 44: 214-221.

Peura, J., Serenius, T. \& Strandén, I. 2005. Economic weights for most important traits in Finnish blue fox production. In: NJF Seminar no. 377: NJF's Subsection for Fur Animals, Uppsala, Sweden, 5-7 October 2005.

Peura, J., Strandén, I. \& Mäntysaari, E.A. 2007. Genetic parameters for Finnish blue fox population: litter size, age at first insemination and pelt size. Agricultural and Food Science. This issue.

Peura, J., Strandén, I. \& Smeds, K. 2004. Genetics of litter size, age at first insemination and animal size in blue fox (Alopex lagopus). In: Urlings, B., Spruijt, B., Ruis, M. \& Boekhorst (eds.), Proceedings of the 8th International Scientific Congress in Fur Animal Production. Part IV-3RP. 'S-Hertogenbosch, The Netherlands, 15-18 September 2004. Scientifur Vol. 28, No. 3. p. $206-210$.

Rendel, J.M. \& Robertson, A. 1950. Estimation of genetic gain in milk yield by selection in a closed herd of dairy cattle. Journal of Genetics 50: 1-8.

VanRaden, P.M. 1992. Accounting for inbreeding and crossbreeding in genetic evaluation of large populations. Journal of Dairy Science 75: 3136-3144.

Wierzbicki H., Peura J., Żuk B. \& Strandén I. 2004. A comparison of inbreeding effect on reproduction and fur coat traits in Finnish and Polish blue fox populations. Proceeding of the XXI Genetic Days, 1-3 September 2004, Wroclaw, Poland. Animal Science Papers and Reports Vol. 22, Suppl. 2. 165-170.

Woolliams, J.A., Mäntysaari, E.A. 1995. Genetic contribution of Finnish Ayrshire bulls over four generations. Animal Production 61(2): 177-187.

Wright, S. 1922. Coefficients of inbreeding and relationship. American Naturalist 56: 330-338. 
Strandén, I. \& Peura, J. Inbreeding and relationship coefficients in the Finnish blue fox population

\section{SELOSTUS}

\section{Sukusiitos ja sukulaisuusaste Suomen sinikettupopulaatiossa}

Ismo Strandén ja Jussi Peura

MTT Biotekniikka- ja elintarviketutkimus

\begin{abstract}
Suomalaisen siniketun koko on jalostusvalinnan vuoksi suurentunut huomattavasti runsaan vuosikymmenen ajan. Tehokas eläinjalostusohjelma voi kuitenkin lisätä sukusiitosta. Tässä tutkimuksessa sukupolvittaisen sukusiitoksen kasvun arvioitiin olevan noin $0.107-0.191 \%$ tarkasteltujen vuosien mukaan. Vuosittainen sukusiitoksen lisäys puolestaan oli arviolta noin $0.059-0.100 \%$. Efektiivinen
\end{abstract}

populaatiokoko arvioitiin vähintään 260 :ksi. Sukusiitos ei siis vaikuta olevan ongelma Suomen sinikettupopulaatiossa. Geneettisesti suurikokoisimpia sinikettuja tuottaneiden tilojen joukossa oli kuitenkin tiloja, joilla sukusiitos poikkesi huomattavasti keskimääräisestä. Näiden tilojen tulisi käyttää nykyistä parempia keinoja sukusiitoksen rajoittamiseksi jalostusvalinnan yhteydessä. 